\title{
The Character Education of Early Childhood: Brain-Based Teaching Approach
}

\author{
Siti Wardah Hanafie Das \\ Muhammadiyah University of Parepare \\ wardahhadas@gmail.com
}

\begin{abstract}
The character education of early childhood through brain-based teaching approach is extremely important to stimulate neocortex and neuron. The study is aimed to formulate the early childhood character based on brain-based teaching approach started from the kindergarten with local wisdom study, analysis of kindergarten vision and mission, analysis of kindergarten curriculum, a test of brainbased teaching, evaluation, and drafting curriculum. The research sample was 59 kindergarten schools in Pare-Pare, South Sulawesi. Data gathering techniques were directed observations, in-depth interviews, and documentation. Data analysis was performed through reduction, data display, and conclusion drawing/verification. There are five components of brainbased teaching in kindergarten; these are 1) social intelligence; 2) emotional intelligence; 3) cognitive intelligence; 4) kinesthetic intelligence; 5) and reflective intelligence. The study was conducted in the form of a workshop with experts to provide character concept to be addressed. Also, the study was conducted to show and design curriculum based on the concept of character and the institutionvision and mission.
\end{abstract}

Keywords: Character, Education, Brain-Based, Kindergarten

\section{INTRODUCTION}

The character education is a contemporary demand in Indonesia. The educational activities are required to provide reinforcement of character for the next generation's (particularly, children from an early age) shield to face more challenging life. The Early Childhood Education Program (Pendidikan Anak Usia Dini) is organized in the form of formal educational institutions, requiring the curricula format and design, relevant with the conditions and dynamics of science learning. The concept of learning in the kindergarten isbased on character and behavior of the learners in kindergarten by stages of children psychological development. The design of contemporary learning systems has spawned a wide range of theories and concepts, among which is the brain based-teaching. Brain-based teaching is learning approach examining the working bases and reasoning power of learners in designing learning [1], [2].

Brain-based Learning is a Learning approach,based on the structure and function of the human brain External factors identified as a trigger for the effectiveness of the learning interaction. Every human being is more likely to experience these four things. They are; 1) trianglerelationship; 2) intrapersonal (relationship with oneself); 3) social relationship (environment); and 4) spiritual (relationship to the Almighty God) [3].

Any outcomes that relationship will provide interpretation or understanding of the values and beliefs eventually become a child. Other kindergarten or elementary school programs focusing on student social attitudes and behaviors have academic effects in middle and/or high school. Character education is definitely also focused on teaching, such as moral, honesty, generosity and tolerance [4], [5].

The main reason whyEarly Childhood Education Program is fundamental because a childhood is a golden period which will not be repeated. This is the most crucial period in the formation of personality, thinking, and social skill. In brain-based learning, the brain could not function well when a child is experiencing stress or anxiety.

That is why character education is crucialto create healthy emotional environment. Early childhood education is expected to grow and develop basic characters. A child, then, has superior capabilities includes;1) an independent character and superior; 2) commitment to the independence and freedom; 3) avoiding latent potential conflict; 4) the significance of unity in diversity; and 5) preventing social stratification related to ethnic and religious differences [6].

The Republic Act No. 20, 2003 on National Education System, Chapter 1, Article 1, Paragraph 14 stated that "the Early Childhood Education Program is a development effort aimed at children from 0 to 6 years of age. This is conducted through the provision of educational stimulation to assist the growth and development of a child physically and mentally in order to have the readiness to enter further education." The law urges early childhood education to provide stimuli in order to adapt and prepare a child to enter the next level of education[7].

The phase of the child development is not always the same with his friends. Hurlock in Jamal (2009) stated that there are 10 aspects of development that could encourage the development of children through education in kindergarten. These are; "health maintenance, training skills, develop the ability to speak, to manage emotions, social behavior training, teaching social attitudes, develop creativity, exercise discipline, to develop selfconcept, and train children adjust to school"[8]. 
The following outlines the treatments according to students' psychological development; a) students in the prenatal developmental stages are keeping maternal physiological environment, maintaining food, maintainingbehavior of parents, and controling of temperament and negative attitudes to their mother; b) students in vital developmental stages are maintaining a meal and child nutrition and habit; c) students in the developmental stages of memory are exercising senses, attention, and memories; d) students in the behavior developmental stages are avoiding pampering treatments, punishment, social life guidance; e) students in the observationsphase are creating a healthy environment and pedagogical, training the observation function, giving examples of positive living, and providing stimulus and objective information; $\mathrm{f}$ ) students in the intellectual developmentstage aretraining to think, giving intrinsic motivation for children to learn auto-active, using evaluation as a means of a learning motivation, and providing counseling fair and flexible psychological [9][10].

\section{METHOD}

The concept of brain-based teaching in the learning activities was tested to measure the effectiveness of the concept after the implementation [11]. This research had six stages; 1) study of the local wisdom; 2) the analysis of kindergarten vision and mission; 3) the study of kindergarten curriculum; 4) brain-based teaching test; 5) evaluation of the concept application; and 6) compilation of the curriculum concept.

\section{Data Gathering}

The data were gatheredfrom various settings, sources, and ways [12]. The descriptive nature of qualitative research and data collectionwere appliedusing 1) participant observation; 2) In-depth interviews; and 3) study documentation.

\section{Data Analysis}

The data analysis technique implemented were adopted from Miles and Huberman, [13] it was performed in three grooves, an integral activity (interrelated).They are; 1) reduction of the word; 2) presentation of data; and 3) drawing conclusions.

\section{RESULT}

\section{Brief Description of Parepare kindergarten}

The total number of Kindergartens in Parepare City, South Sulawesi is about 59 which are segregated into four districts; 19 in Soreang district, 16 in Edge district, 20 in West Bacukki district, and 4 in Bacukiki district (See table 1).

The character education with the application of brain-based learning in kindergarten in Parepare City was a new approach, which has not been formally implemented administratively in schools, but it has technically already been implemented in the form of operational indicators partially.

Table 1: Category of Population of Early Childhood (5-6 years of age) in Parepare

\begin{tabular}{|c|c|c|c|c|}
\hline \multirow{2}{*}{ No. } & \multirow{2}{*}{ District } & \multicolumn{2}{|c|}{ Gender } & \multirow{2}{*}{ Number } \\
\hline & & Male & Female & \\
\hline 1 & Soreang & 767 & 804 & 1571 \\
\hline 2 & Ujung & 599 & 620 & 1219 \\
\hline 3 & $\begin{array}{l}\text { Bacukiki } \\
\text { Barat }\end{array}$ & 744 & 780 & 1524 \\
\hline 4 & Bacukiki & 263 & 316 & 579 \\
\hline & Tota 1 & 2373 & 2520 & 4893 \\
\hline
\end{tabular}

The Character Education of Early Childhood Implementation at BBT kindergarten in Parepare

From an interview with Ms. Patima, one of the teacher,it could be highlighted the learning in kindergarten used the area system. It was divided 5 groups.The students are directed to the existing area, such as the area of art, the area of religion, the area of the beam, and so on. Five groups were rotated to enter each area orderly. Then 3 groups of educators were assigned to supervise them. (Pat, 2013).

In an actual observations during the workshop on "PAUD Character Education Workshop, August 27, 2013", the character education which could be developed in kindergarten Parepare is a religious character, honesty, tolerance, discipline, hard working, creativity, independence, democratic, curiosity, nationalism, patriotism, excellence recognition, communication, peace-loving, fond of learning, environmental care, social care, and responsibility. The components of brain-based teaching are social, emotional, cognitive, kinesthetic, and reflective. Explanation of brain-based teaching are as follows:

\section{Social intelligence}

Application of brain-based teaching for early childhood, particularly related to the development of social intelligence, could be done through workingand playingtogether; greeting politely; and praising the work of others.

Social intelligence variable sabove shows the urgency for educators to have the knowledge and commitment in educating students according to the procedure of early childhood brain works. Children need to understand and remember the power of reason for the importance of social life and maintain the integrity and friendship in the social life. A child will receive a positive stimulus for the development of intelligence if it can interact with her because this moment can co-exist and explore higher.

\section{Emotional intelligence}

Orientation learning emphasizing the development of emotional intelligence isrevelant to teach and urgentlyneeded for application since early childhood. Regarading to the implementation of brain-based teaching, the teachers are required to implement it according to RKH and action plans that have been prepared. The learning themes in RKM are adjusted based on the level 
of the child's thinking ability, so learning activities can run smoothly.

The character education aspects of emotional intelligences are tolerance, emotional expression in accordance with existing conditions; the etiquette and manners understanding; regulations comprehension; empathy; persistent attitude; confidence; and appreciating of others.

Developing emotional intelligence in early childhood must be adapted to the absorptive capacity of the child, the child's reasoning mental development, the ability to select good and bad things, and the ability to classify different characteristics, and so on.

\section{Cognitive intelligence}

The variables for weekly cognitive teaching plan areto classify objects based on the function; to indicate explorative and investigate activity; to know the cause and effect on the environment; to demonstrate initiative in choosing the theme of the game; to solve simple problems in daily life; to differ based on sizes; to classify objects based on color, shape, and size; to sort the objects from the smallest size to largest or vice versa.

The Character Education of Early Childhood in kindergarten with brain-based learning approach should be able to excite and delight the students active participation in learning. Development of cognitive intelligence variables must take into account the students' ability, the materials, props, and methods so the education can provide stimulation to the brain.

\section{Kinesthetic intelligence}

The kinesthetic intelligence in this type of education includes moving the body and legs in order to develop balance, strength, agility, and courage. Then students can coordinate the movement of the hand-foot-heads in performing dance / gymnastics; conduct regular physical game; move the hand to muscle tone and coordination; conduct personal hygiene; draw the corresponding idea; explore a variety of media; and express self-portrait in detail.

Development of kinesthetic intelligence is very importantfor early childhood. Muscles which are supple, well-coordinated, balance, andstrongneeds to be developed. Also, motor aspects should also be developed. As a result, the students are able to dance, hold writing instruments, cut, comb hair, brush your teeth, and so on. Consequently, kinesthetic intelligence development will affect the students' reasoning skills (brain), resulting in harmonization between motor movement (coarse and fine) with brain development.

\section{Reflective intelligence}

Development of reflective intelligence is related to the students' understanding on themes such as, my needs, environment, animal, plants, the universe, work, communication tools etc.

In addition, the students are required to be taught about religious topics, such as; understanding basics of worship; knowing basic letters of the Al-Qur'an; distin- guishing good and bad behavior; knowing the religious holidays; respecting other religions; and knowing the story of exemplary characters.

The students can receive reflective learning oriented according to the power of his reason or appropriate brain working processes. If the introduction of a range of reflective themes is introduced since their early education. The students will develop effective reflective intelligence.

\section{CONCLUSION}

The early childhood learning as a brain-based approach is considered a new to the world of Early Childhood Education Program. It is considered to be very relevant to be implemented in the kindergartento develop the work and development of the students' brain. In other words, proper handling in early childhood learning will lead to the significance of brain development in a positive way. Teachers are required to work professionally following program plan, designed annually, weekly, and daily. Also they are required to keep monitoring the development of learners' reasoning power related to social, emotional, cognitive, kinesthetic, and reflective intelegences.

\section{REFERENCES}

[1] D. Sutopo, "The Interlanguage of Indonesian Young Learner of English : A Case Study on an Indonesian Bilingual School Kindergarten Student 's English Speaking Acquisition," $J$. Educ. Pract., 2013.

[2] V. Adriany and J. Warin, "Preschool teachers' approaches to care and gender differences within a child-centred pedagogy: findings from an Indonesian kindergarten," Int. J. Early Years Educ., 2014

[3] H. Universitas Negeri Yogyakarta. Program Studi Pendidikan Luar Sekolah and W. Ikatan Akademisi Pendidikan Nonformal dan Informal Indonesia, Jurnal pendidikan dan pemberdayaan masyarakat. 2015.

[4] P. W. Wijayanto and Y. Siradj, "The Educational Game 'Indonesian Tribes ' for the Kindergarten Students,” Int. J. Pedagog. Teach. Educ., 2012.

[5] M. Solehuddin and V. Adriany, "Kindergarten teachers' understanding on social justice: stories from Indonesia," SAGE Open, 2017.

[6] I. S. Borualogo, "Optimalisasi Pendidikan Anak Usia Dini (Paud) Guna Meningkatkan Indeks Pembangunan Manusia (Ipm) Di Jawa Barat," Mimbar, 2006.

[7] A. L. Belakang et al., "Universitas Sumatera Utara," Pemberian Cairan Karbohidrat Elektrolit, Status Hidrasi dan Kelelahan pada Pekerja Wan., 2012.

[8] S. K. D. A et al., "Belajar Melalui Bermain untuk Pengembangan Kreativitas dan Kognitif Anak Usia Dini," Surya, 2016. 
[9] A. Nirwana, "Perancangan Situs Jaringan dan Media Promosi TK Al-Azhar Kids World Malang," J. Ilm. Teknol. Inf. Asia, 2012.

[10] R. N. Hidayati, "Komputerisasi Pengolahan Data Penerimaan Peserta Didik Baru Di Smk Negeri 3 Pati Berbasis Intranet," J. Speed - Sentra Penelit. Eng. dan Edukasi, 2013.
[11] S. M. Sari, "Peran Warna Interior Terhadap Perkembangan Dan Pendidikan Anak Di Taman Kanak-Kanak," Dimens. Inter., 2004.

[12] M. S. Lewis-Beck, "Data Gathering," in Data analysis: an introduction, 1995.

[13] Deakin University, "Data Gathering," J. Chem. Inf. Model., 2013. 